Plant Biosystems - An International Journal Dealing with all Aspects of Plant Biology

Official Journal of the Societa Botanica Italiana

\title{
Population genetic structure of Gymnospermium scipetarum subsp. eddae (Berberidaceae), an endangered Forest endemic from the Southern Apennines (Italy)
}

\author{
S. Marzario, T. Gioia, G. Logozzo, S. Fascetti, A. Coppi, F. Selvi, E. Farris \& L. \\ Rosati
}

To cite this article: S. Marzario, T. Gioia, G. Logozzo, S. Fascetti, A. Coppi, F. Selvi, E. Farris \& L. Rosati (2021): Population genetic structure of Gymnospermium scipetarum subsp. eddae (Berberidaceae), an endangered Forest endemic from the Southern Apennines (Italy), Plant Biosystems - An International Journal Dealing with all Aspects of Plant Biology, DOI: 10.1080/11263504.2021.1992524

To link to this article: https://doi.org/10.1080/11263504.2021.1992524

\section{曲 Published online: 10 Nov 2021.}

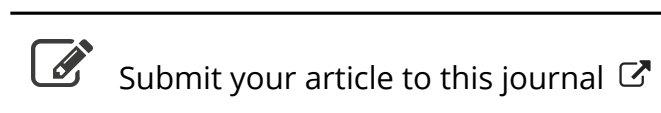

\section{Џ Article views: 11}

\section{Q View related articles ¿}

View Crossmark data ¿ 


\title{
Population genetic structure of Gymnospermium scipetarum subsp. eddae (Berberidaceae), an endangered Forest endemic from the Southern Apennines (Italy)
}

\author{
S. Marzario ${ }^{a}$, T. Gioiaa ${ }^{a}$ G. Logozzo ${ }^{a}$, S. Fascetti ${ }^{a}$ (D) A. Coppi ${ }^{b}$ (D) F. Selvic (D) E. Farris ${ }^{d}$ (D) and \\ L. Rosatia
}

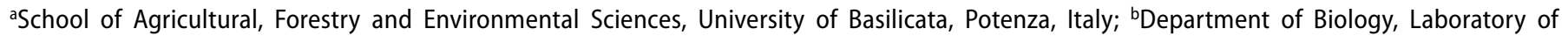
Botany, University of Florence, Firenze, Italy; 'Department of Agriculture, Food, Environment and Forestry, University of Florence, Firenze, Italy; ${ }^{\mathrm{d} D e p a r t m e n t}$ of Chemistry and Pharmacy, University of Sassari, Sassari, Italy

\begin{abstract}
Assessing genetic diversity of narrow endemic plants is essential for their conservation. Gymnospermium scipetarum subsp. eddae (Berberidaceae) is an Italian endemic limited to a narrow forest area in the southern Apennines. Here we used random amplified polymorphic DNA (RAPD) markers to investigate population genetic differentiation and diversity in relation to distribution and microhabitat conditions. In all five extant populations and 134 individuals analysed we found a relatively low level of population genetic diversity (average Shannon-Weaver diversity index = 0.280 ; mean percentage of polymorphic bands $=57.45 \%$; mean Nei's gene diversity $\mathrm{H}_{\mathrm{e}}=0.187$ ). Percentage of polymorphic bands (PPB) at species level was higher than at the population level $(83.33 \%)$, while total species diversity $\left(H_{e}=0.210\right)$ was comparable to that found in the two southernmost subpopulations. AMOVA revealed a weak differentiation among populations, which shared three genetic pools in their genetic structure. The estimated gene flow among populations was relatively high (mean $\mathrm{N}_{\mathrm{m}}=5.320$ ), while the Mantel test revealed no significant correlation between geographical and genetic distances at the population level. We argue that information on genetic diversity of $G$. eddae have important implications for conservation programmes, particularly for the establishment of ex-situ collections and restocking conservation actions.
\end{abstract}

\section{ARTICLE HISTORY}

Received 9 April 2021

Accepted 8 October 2021

\section{KEYWORDS}

Endemic plant;

plant conservation;

population genetic structure; RAPD

\section{Introduction}

Population genetic diversity is one of the major factors determining the ability of a species to adapt to environmental variations. Low levels of variability and genetic depletion are commonly associated with a higher risk of local extinction (Jump et al. 2009; Jacquemyn et al. 2012; Schlaepfer et al. 2018), explaining why the maintenance of adequate levels of genetic diversity is deemed necessary to assure the evolutionary potential of a species (Frankham 2005; Solórzano et al. 2016; Hatmaker et al. 2018). This is reflected in the Convention on Biological Diversity (CBD), where conservation of genetic diversity was considered a key point of the Strategic Plan 2011-2020. Narrow-ranged endemic taxa are frequently characterized by low levels of genetic variability due to the combined effect of random genetic drift, reduced gene flow and inbreeding, following the formation of small and isolated populations for natural or anthropogenic causes (Ellstrand and Elam 1993; Leimu et al. 2006). Hence, assessing genetic diversity of endemic plants with a restricted area of occupancy is necessary to plan species recovery actions, restocking or ex-situ conservation strategies (Heywood 2019). On the other hand, there is evidence that genetic depletion is not always the case in narrow-ranged endemics depending on a range of factors associated with the species history, life-traits and habitat dynamics (González-Astorga and Castillo-Campos 2004; Turchetto et al. 2016).

With ca. 25,000 vascular plants in an area of ca. 2.3 million $\mathrm{km}^{2}$, the Mediterranean region is one of the most important biodiversity hotspots at the global scale (Medail and Quezel 1999; Myers et al. 2000; Thompson 2020). A characteristic feature of the Mediterranean flora is the high endemism rate, since ca. $60 \%$ of the vascular plants are exclusive to this area, and $60 \%$ of them are confined to a single, restricted part of the region; this means that ca. $1 / 3$ of the Mediterranean vascular plants are narrow endemics (Thompson 2020). So far, only a very minor proportion of these taxa has been analysed for population genetic structure, and evidence exists that variability can be higher than expected based on population size and extent of the species range (e.g. Coppi et al. 2008; Bacchetta et al. 2013; Jiménez-Mejías et al. 2015; Forrest et al. 2017).

In particular, the genetic structure and diversity of endemic plants that grow in the understorey of Mediterranean forests have been poorly investigated, even when compared to 
non-forest endemics of the same region. However, Mediterranean forests are species-rich and highly dynamic habitats, subjected, over a long period of time, to chronic and stochastic disturbances of natural and anthropogenic origin such as cutting, grazing, fires, increasing herbivore pressure, fragmentation, and land-use changes. Effects of these disturbances on understorey endemic plants are largely unknown, though potentially dramatic via changes of forest microclimate, soil conditions, shifts in community species composition and competition relations (Landuyt et al. 2019). Actually, the signatures of past and current disturbances on understorey species can be detected in the structure, distribution and habitat conditions of the populations, as well as in their genetic structure and variability. Understanding the type and magnitude of these signatures in the face of past disturbances can provide a measure of the species adaptive ability and help to predict their responses to future changes to their habitat. Such information is crucial to plan forest management strategies that can mitigate the negative effects of disturbances on vulnerable understorey plants with narrow ecological niches, as in the case of the endemics with small effective population sizes.

Italian forests harbour numerous understorey endemics in different phylogenetic lineages, biogeographic regions and forest types, especially in the southern and insular regions. The most recently described Italian forest endemic belongs to Gymnospermium Spach (Berberidaceae), a small genus of about 12 species distributed across Eurasia from the Korean Peninsula, at the East, to southern Italy, at the western limit (Barina et al. 2017). The only Italian meta-population of this genus was discovered a few years ago in the beech and oak forests of the Maddalena mountains of the Southern Apennines (Rosati et al. 2014). Based on morphometric and molecular phylogenetic analyses, this population was found to be closely related to those of the Balkan species G. scipetarum E. Mayer \& Pulević from Albania and Montenegro and was described as G. scipetarum subsp. eddae Rosati, Farris, Fascetti \& Selvi (hereafter referred to as G. eddae; Rosati et al. 2019a). At the present state of knowledge, only few fragmented subpopulations of this taxon do exist within an occupancy area of less than five $\mathrm{km}^{2}$ when measured on a $1.1 \mathrm{~km}$ grid (Rosati et al. 2019a). Of these subpopulations, four are relatively large and formed by several hundreds of individuals. Although the range of $G$. eddae is completely included in the Natura 2000 site IT8050034 "Monti della Maddalena," no specific legal conservation measures currently exist. Hence, this taxon provides an ideal model system to investigate the genetic structure of a rare understorey forest endemic with high biogeographic interest, fragmented distribution and a potentially high extinction risk.

To support conservation strategies of $G$. eddae, our research group has recently prompted a series of in-depth research on its reproductive biology (unpubl. data). Moreover, a cooperation agreement has been recently established with the Botanical Garden of the Majella National Park, an Apennine protected area particularly active in the field of plant diversity conservation (Di Cecco et al. 2020), with the aim to implement specific ex-situ conservation actions for this taxon.

In the present work, we investigated for the first time the genetic structure and diversity of $G$. eddae by applying Random Amplified Polymorphic DNA (RAPD). Despite some limits connected to data reproducibility (Ramos et al. 2008 and references therein), RAPDs are considered a useful method to evaluate genetic characteristics of populations of rare and endangered species (e.g. Torres et al. 2003; Conte et al. 2004; Ku et al. 2004) and able to provide similar estimates with respect to other dominantly inherited markers (Nybom 2004). Both RAPDs and allozymes were successfully used for the only other species of Gymnospermium that has been previously analysed for population genetic structure and conservation biology, G. microrrhyncum (S. Moore) Takht. from South Korea (Chang et al. 2004; Lee et al. 2016). Hence, knowledge about populations genetic variability in species of Gymnospermium is still very scarce and in need of more studies.

Accordingly, the specific objectives of this study were: 1) to assess the genetic structure of $G$. eddae by analysing variability within and between subpopulations, in order to define conservation units; 2) to determine the relation between genetic diversity and geographic distribution of subpopulations, thus testing the isolation by distance hypothesis (IBD); 3) to provide guidelines for effective conservation strategies.

\section{Materials and methods}

\section{The study species}

Gymnospermium eddae is an early flowering geophyte, with showy inflorescences which develop before the appearance of leaves. Racemes have 8-13 flowers, with bright yellow corollas measuring $17-30 \mathrm{~mm}$ in diameter. Flowering occurs from early March to April in mesic temperate deciduous woodlands of Fagus sylvatica L. and Quercus cerris L. All known populations are restricted to a single sector of the southern Apennines, the Maddalena Mountains (Province of Salerno, Administrative region of Campania, S-Italy), at an altitude of $1000-1300 \mathrm{~m}$ a.s.l. (Figure 1). The area occupied by all extant populations of $G$. eddae, ascertained in this work, resulted very small, about only $1.85 \mathrm{ha}$, and the effective area of occupancy is much smaller than previously calculated on the basis of a $1 \times 1 \mathrm{~km}$ grid (approx. five $\mathrm{km}^{2}$, Rosati et al. 2019a). Based on these data, G. eddae is certainly one of the rarest and most localized Italian endemic forest plant. Fruits are set in May, when seeds become exposed following the split of membranous pericarp. Seeds are fleshy, 7-11 mm long, with a whitish strophiole interpreted as an adaptation for myrmecochory (Lengyel et al. 2009). Plants reproduce sexually, while asexual reproduction does not seem to occur (LR, pers. obs.). Floral morphology and composition of the pollinator community indicate a generalist pollination syndrome. Muscoid flies (e.g. Calliphoridae) and solitary Hymenoptera (e.g. Halictidae) were observed to be the main pollinators (Rosati et al. 2019b). Field experiments on capped racemes for insect exclusion suggested that pollinators are 


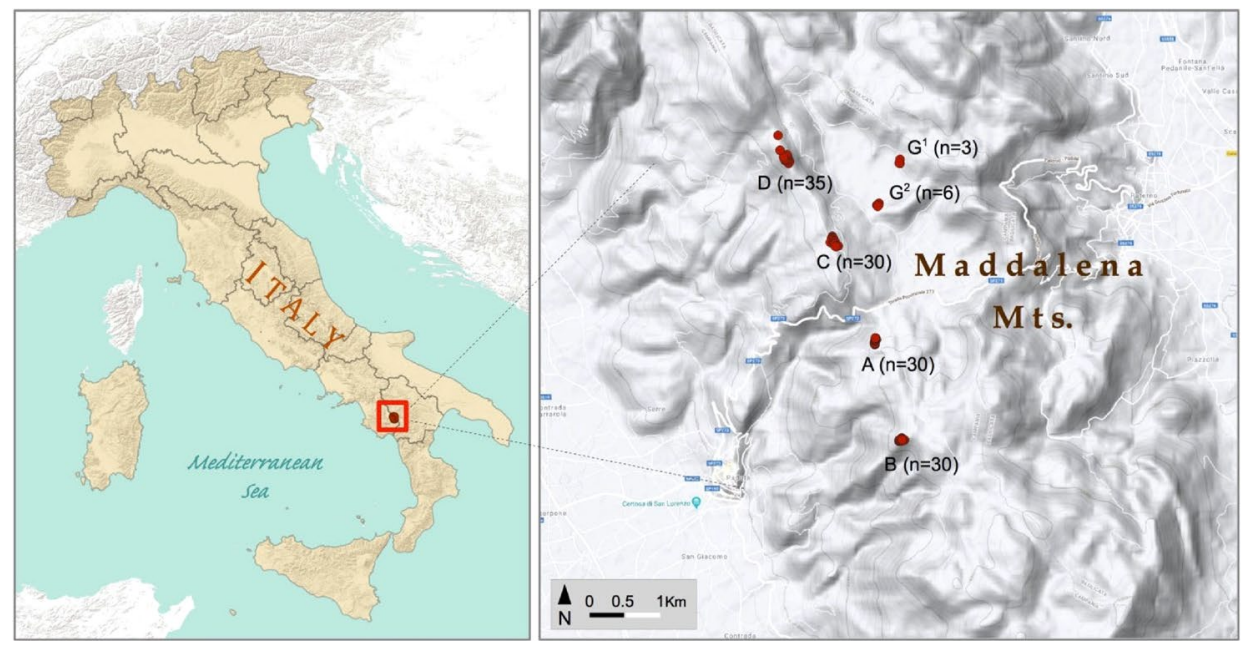

Figure 1. Study area and location of subpopulations of Gymnospermium eddae; in brackets the number of plants analysed for each subpopulation.

necessary for seeds production and, therefore, that $G$. eddae is an allogamous plant (Rosati et al. 2019b). This endemic is diploid with $2 n=14$, a chromosome number shared with the Balkan group of $G$. scipetarum/maloi but not with all other Gymnospermium species investigated so far, which have $2 n=16$ (Rosati et al. 2019a).

\section{Sampling of plant material}

Six subpopulations of $G$. eddae, here indicated as A, B, C, D, $G^{1}, G^{2}$, were identified and sampled in the Maddalena mountains (Figure 1). At the present state of knowledge, they represent the whole taxon range. For sampling purposes, we considered as different subpopulations all groups of individuals that are separated from each other by a distance > $500 \mathrm{~m}$. The maximum and minimum distance between subpopulations (calculated from centroids) was $4.75 \mathrm{~km}$ (B vs. D) and $1.05 \mathrm{~km}$ (C vs. D), respectively. Subpopulations $A-D$ are relatively large, hosting several hundreds of individuals, and are all located in mixed $F$. sylvatica/Q. cerris forests. Subpopulations $\mathrm{G}^{1}$ and $\mathrm{G}^{2}$ are very small and located at lower altitude, in disturbed and secondary habitats (road margin, shrublands). Due to the low number (9) of individuals detected in April 2017 and the similar habitat type, subpopulations $G^{1}$ and $G^{2}$ were grouped together for the purposes of the statistical analysis (Figure 1), though $740 \mathrm{~m}$ far from each other. Overall, 134 individuals were sampled in five subpopulations (A-G): 30 in subpopulations $A, B$ and $C$ and 35 in subpopulation $D$. The main features of sampling locations and habitat are shown in Table 1 and Supplementary Figure S1, respectively.

Two or three leaflets were collected from each individual during the peak of the growing season (April 2017). To avoid collecting ramets from the same individual, the minimum distance between samples was set to $1 \mathrm{~m}$. Localization of each sampling point was retrieved on-field using a GPS receiver (GARMIN) with differential correction, leading to position accuracy of $\pm 2 \mathrm{~m}$. After collection, leaf samples were transported in ice to the laboratory and stored at $-80^{\circ} \mathrm{C}$ until DNA extraction.

\section{DNA extraction and RAPD analysis}

DNA was extracted from leaf samples using a DNeasy ${ }^{\circledR}$ Plant Mini Kit (Qiagen). The DNA integrity was determined on 1\% agarose gel, and the DNA quantity and quality were verified using a NanoDrop ${ }^{\oplus}$ ND-1000 Spectrophotometer (NanoDrop Technologies). Each DNA sample was diluted to $25 \mathrm{ng} / \mu \mathrm{L}$ with

Table 1. Characteristics of the sampling locations and sample size of each subpopulation of Gymnospermium eddae studied.

\begin{tabular}{|c|c|c|c|c|c|c|c|c|c|}
\hline Subpopulation & Longitude & Latitude & $\begin{array}{l}\text { Altitude (m } \\
\text { a. s.l.) }\end{array}$ & Lithology & Morphology & Habitat & $\begin{array}{c}\text { Sample size } \\
(n)\end{array}$ & $\begin{array}{l}\text { Subpopulation } \\
\text { size }(n)\end{array}$ & Area $\left(\mathrm{m}^{2}\right)$ \\
\hline A & 558172 & 4467898 & 1150 & $\begin{array}{l}\text { Siliceous } \\
\text { schists }\end{array}$ & $\begin{array}{l}\text { Mountain ridge/ } \\
\text { slope }\end{array}$ & $\begin{array}{l}\text { Quercus cerris/Fagus } \\
\text { sylvatica } \\
\text { high forest }\end{array}$ & 30 & $>500$ & 1120 \\
\hline B & 558612 & 4466358 & 1275 & $\begin{array}{l}\text { Siliceous } \\
\text { schists }\end{array}$ & Mountain ridge & $\begin{array}{l}\text { Quercus cerris/Fagus } \\
\text { sylvatica } \\
\text { coppice with stand/ } \\
\text { forest edge }\end{array}$ & 30 & $>500$ & 1920 \\
\hline C & 557521 & 4469421 & 1225 & $\begin{array}{l}\text { Siliceous } \\
\text { schists }\end{array}$ & $\begin{array}{l}\text { Mountain ridge/ } \\
\text { slope }\end{array}$ & $\begin{array}{l}\text { Fagus sylvatica/Quercus } \\
\text { cerris } \\
\text { high forest }\end{array}$ & 30 & $>500$ & 3664 \\
\hline D & 556799 & 4470750 & 1300 & $\begin{array}{l}\text { Siliceous } \\
\text { schists }\end{array}$ & $\begin{array}{l}\text { Mountain ridge/ } \\
\text { slope }\end{array}$ & $\begin{array}{l}\text { Fagus sylvatica } \\
\text { coppice with stand/ } \\
\text { high forest }\end{array}$ & 35 & $>1000$ & 10830 \\
\hline G & 558225 & 4470003 & 1070 & Alluvial & Karst floodplain & Road margins/shrublands & 9 & $<15$ & 961 \\
\hline
\end{tabular}

Coordinates are projected in UTM $33 \mathrm{~N}$, datum WGS84. 
Table 2. List of primers used to evaluate genetic diversity of Gymnospermium eddae and relative sequences, total number of bands, polymorphic bands and rare bands.

\begin{tabular}{|c|c|c|c|c|c|c|}
\hline \multirow[b]{2}{*}{ Primer } & \multirow[b]{2}{*}{$\begin{array}{r}\text { Sequence } \\
(5 \bigotimes-3 \bigotimes)\end{array}$} & \multicolumn{2}{|c|}{ G. eddae } & \multicolumn{2}{|l|}{ G. microrrhyncum } & \multirow[b]{2}{*}{$\begin{array}{c}\text { Polymorphic } \\
\text { bands }\end{array}$} \\
\hline & & $\begin{array}{c}\text { Total no. of } \\
\text { bands }\end{array}$ & $\begin{array}{c}\text { Polymorphic } \\
\text { bands }\end{array}$ & Rare bands $(p<0.05)$ & $\begin{array}{c}\text { Total no. of } \\
\text { bands }\end{array}$ & \\
\hline OPA--08 & GTGACGTAGG & 11 & 9 & 2 & 10 & 10 \\
\hline OPA--10 & GTGATCGCAG & 5 & 3 & 1 & 9 & 9 \\
\hline OPAF--07 & GGAAAGCGTC & 4 & 1 & 0 & 10 & 10 \\
\hline OPAF--20 & CTCCGCACAG & 16 & 14 & 3 & 10 & 10 \\
\hline OPN--03 & GGTACTCCCC & 12 & 7 & 3 & 10 & 10 \\
\hline OPN--13 & AGCGTCACTC & 18 & 18 & 6 & 13 & 13 \\
\hline OPO--06 & CCACGGGAAG & 19 & 17 & 4 & 12 & 11 \\
\hline OPP--05 & CCCCGGTAAC & 17 & 16 & 7 & 4 & 4 \\
\hline Mean & & 12.75 & 10.63 & 3.25 & 9.75 & 9.63 \\
\hline Total & & 102 & 85 & 26 & 78 & 77 \\
\hline
\end{tabular}

Total number of bands and polymorphic bands are compared to values obtained in G. microrrhyncum by Lee et al. (2016) using the same primers.

double-distilled water before assessing polymorphism using eight RAPD primers (Operon RAPD ${ }^{\circledR}$ 10-mer kit, Sigma-Aldrich) from the $A, F, N, O$ and $P$ series selected on the basis of their reproducible and distinct banding patterns (Lee et al. 2016) (Table 2). PCR amplifications were performed in a total volume of $20 \mu \mathrm{L}$ containing $25 \mathrm{ng}$ genomic DNA, $1 \mathrm{U}$ DreamTaq DNA Polymerase (Thermo Scientific), $2 \mu \mathrm{L}$ 10X DreamTaq Green Buffer, $1 \mu \mathrm{L}$ dNTP mixture ( $2.5 \mathrm{mM}$ each), $2 \mu \mathrm{L}$ primer (20 pmol) and double-distilled water. PCR amplifications were conducted in a GeneAmp ${ }^{\circledR}$ PCR System 9700 Thermocycler under the following conditions: initial denaturation at $94^{\circ} \mathrm{C}$ for $2 \mathrm{~min}$; 39 cycles at $94^{\circ} \mathrm{C}$ for $30 \mathrm{~s}$ (denaturation), $36^{\circ} \mathrm{C}$ for $30 \mathrm{~s}$ (annealing), and $72^{\circ} \mathrm{C}$ for $1 \mathrm{~min}$ (extension); with a final extension at $72^{\circ} \mathrm{C}$ for $10 \mathrm{~min}$. The PCR products were separated by electrophoresis on $1.4 \%$ agarose gels in $0.5 \mathrm{X}$ TBE buffer, and visualized using $S_{Y B R}{ }^{\oplus}$ Safe DNA gel stain. Electrophoretic patterns were documented using the Gel Doc $^{\text {TM }} 2000$ gel Imaging System (Bio-Rad Laboratory).

\section{Data analysis}

RAPD profiles were scored manually and a binary data matrix was obtained, with 0 and 1 indicating, respectively, the absence or presence of a given band. Estimates of allelic frequencies at RAPD loci were calculated on the basis of the observed frequencies of the bands. The level of genetic variation in the whole sample of $G$. eddae individuals and in each subpopulation was evaluated as percentage of polymorphic bands (PPB) in relation to the number of total bands, observed number of bands per locus $\left(\mathrm{N}_{\mathrm{a}}\right)$, effective number of alleles per locus $\left(\mathrm{N}_{\mathrm{e}^{\prime}}\right.$, Hartl and Clark 1989), genetic diversity within population $\left(\mathrm{H}_{\mathrm{e}}, \mathrm{Nei}\right.$ 1987) and Shannon-Weaver diversity index (I).

RAPD bands (fragments) common to all five subpopulations, shared between at least two subpopulations or unique for each subpopulation were identified, and the number of rare bands $(p<0.05)$ was also calculated. They were classified as local rare and local common (Marshall and Brown 1975). Divergence among subpopulations was described according to the frequency and distribution of fragments.

Genetic diversity statistics (Nei 1978) were also computed for each subpopulation and overall in order to evaluate the proportion of genetic diversity distributed among the five subpopulations.

Additionally, the coefficient of genetic differentiation, $\mathrm{F}_{\mathrm{ST}}$ which measures the relative degree of gene differentiation among subpopulations, was computed. In the analysis of dominant markers, including RAPDs, Wright's $F_{S T}$ (Hartl and Clark 1989) is calculated according to the formula:

$F_{S T}=D_{S T} / H_{T}$, where: $H_{T}=H_{S}+D_{S T}$, and $D_{S T}=\left(H_{T}-H_{S}\right) ; H_{T}$ being the total genetic diversity for the populations, $H_{S}$ the genetic diversity within each population, and $D_{S T}$ the genetic diversity between populations.

Wright (1978) proposed that values of $F_{S T}>0.25$ support significant differentiation between subpopulations, while values of 0.15-0.25 indicates moderate differentiation; differentiation is negligible when $\mathrm{F}_{\mathrm{ST}}$ is 0.05 or less.

To estimate the gene flow or proportion of genes exchanged by populations (as number of migrants, $N_{m}$ ), we used the formula $\mathrm{N}_{\mathrm{m}}=0.5\left(1-F_{\mathrm{ST}}\right) / F_{\mathrm{ST}}$, where $\mathrm{N}$ is the effective population size and $\mathrm{m}$ is the migration rate (Slatkin and Barton 1989). Additionally, genetic distance (Nei 1978) between all pairs of subpopulations was computed. The similarity matrix based on RAPD data and generated by the Nei's genetic distance was used to perform a cluster analysis based on unweighted pair-group method with arithmetic average (UPGMA). All analyses were performed using POPGENE v. 1.32 (Yeh and Boyle 1997).

Principal coordinates analysis (PCoA) was carried out in GenAlEx version 6.5 (Peakall and Smouse 2012) and results were plotted in the bidimensional space defined by the first and the second axis to summarize and visualize the relationships among subpopulations.

Hierarchical analysis of molecular variance (AMOVA, Excoffier et al. 1992) was computed to estimate the partitioning of genetic variation among the five subpopulations and among individuals within each subpopulation. The significance of the variance components was tested by calculating their probabilities based on 9,999 random permutations.

The model-based approach implemented in the software package STRUCTURE (version 2.3.4, Pritchard et al. 2000) was applied to infer population structure. Twenty independent simulations were performed for each $\mathrm{K}$ setting using the admixture model, with each simulation set to a 100,000 burn-in period and 100,000 Markov chain Monte Carlo 
(MCMC) repetitions. To determine the optimal number of clusters, STRUCTURE HARVESTER (Earl and von Holdt 2012) was used to calculate the Delta K statistical test in combination with the likelihoods (posterior probabilities) of each preselected K. Results from simulations with the highest likelihood within each number of different $\mathrm{K}$ simulations were chosen to assign accessions to populations. Individuals with a population membership coefficient $<0.7$ were classified as admixed (Pritchard et al. 2000; Gioia et al. 2013; Marzario et al. 2018).

To verify whether $G$. eddae subpopulations have recently experienced a severe reduction in effective population size, the total amount of mismatches between all pairs of individuals in a population was also estimated with Arlequin vers. 3.5.2.2 (Slatkin and Hudson 1991; Rogers and Harpending 1992; Coppi et al. 2008; Excoffier and Lischer 2010).

Finally, the correlations between genetic distances and geographic distances among subpopulations was assessed using the linear correlation model and Mantel test as implemented in PAST version 4.04 (Hammer et al. 2001).

\section{Results}

The electrophoretic RAPD patterns yielded a total of 102 scorable bands (Table 2) with an average number of 12.75 bands per primer. The number of RAPD bands ranged from 4 (OPAF-07 primer) to 19 (OPO-06 primer).

All the primers yielded polymorphic bands ( $\min 1$ from OPAF-07, max 18 from OPN-13, overall mean 10.63), amounting to $85(83.33 \%$ polymorphism) across the whole set of 134 genotypes. Within each subpopulation, the percentage of polymorphic bands ranged from $44.12 \%$ (45 polymorphic bands) for subpopulation $G$ to $69.61 \%$ (71 polymorphic bands) for subpopulation B, with a mean value of $57.45 \%$ (Table 3).

Within the five subpopulations, the mean number of rare bands (i.e. with a frequency $<0.05 \%$ ) was 7 , ranging between 6 in subpopulation $D$ and 12 in subpopulation $B$; no rare bands were detected in subpopulation $\mathrm{G}$ (Table 3). Seventy out of 102 RAPD bands were common to all subpopulations, as shown in Table S1 (Supplementary Materials). The maximum number of common bands was detected by OPO-06 with 14 bands and the minimum number by OPA-10 with three common bands. No shared bands were detected for OPA-8, OPAF-07 and OPAF-20 primers, which displayed 9, 4 and 12 common fragments, respectively (Supplementary Materials Table S1). Additionally, OPAF-20 revealed 4 unique bands (private bands) in subpopulation $A$ and OPA-8 only two local bands in subpopulations B and G. About $15 \%$ of the bands were shared between at least two subpopulations: $B$ and $C$ shared 14 bands. On the contrary, subpopulation $G$ had the lowest number of bands (4) shared with any of the other four subpopulations. Finally, $15.7 \%$ of the bands were present only in one subpopulation, with subpopulations A and $B$ displaying the highest number of private bands. Instead, subpopulation D had no private bands.

The effective number of fragments per locus $\left(\mathrm{N}_{\mathrm{e}}\right)$ was 1.359 when considering all the $G$. eddae individuals, and decreased slightly from subpopulations $B$ to $G\left(\mathrm{~N}_{e}=1.375\right.$ vs. 1.280; Table 3). Total Nei's genetic diversity $\left(\mathrm{H}_{\mathrm{e}}\right)$ was 0.210 ; the highest value shown in subpopulation $B\left(H_{e}=0.218\right)$, and the lowest ones in $\mathrm{D}$ and $\mathrm{G}\left(\mathrm{H}_{\mathrm{e}}=0.169\right.$ and $\mathrm{H}_{\mathrm{e}}=0.162$ respectively). Shannon-Weaver diversity index was lowest in $G(I=0.240)$ and highest in $B(I=0.329)$, with a mean value of 0.280 .

Genetic diversity indices showed a similar pattern and were highly correlated $\left(r^{2}>0.9 ; p<0.002\right)$. A significant gradient of decreasing genetic diversity $\left(r^{2}=0.96 ; p<0.001\right)$ was found moving from the southern (B) to the northern subpopulations (Figure 2); conversely, longitude and altitude were not significantly related to genetic diversity $(p>0.05)$. The total proportion of polymorphic bands (83.3\%) was higher than at subpopulation level (Table 3), but overall Nei's genetic diversity of $G$. eddae $\left(H_{e}=0.210\right)$ was comparable with that in the two southernmost subpopulations $A$ and $B$ (0.197 and 0.218, respectively).

Partitioning of genetic variation detected by AMOVA (Table 4) revealed that only $9.9 \%$ of the total genetic variation was due to differences among subpopulations, while differences among individuals within populations accounted for a proportion as high as $90.1 \%$. The difference between the individuals within the five $G$. eddae subpopulations was highly significant $(p<0.0001)$.

Geographical and Nei's genetic distances among the five subpopulations are shown in Table 5, together with Wright $\mathrm{F}_{\text {ST }}$ values and estimated levels of gene flow $\left(\mathrm{N}_{\mathrm{m}}\right)$. These levels were relatively high (mean $\mathrm{N}_{\mathrm{m}}=5.32$ ), ranging between 10.20 in $C$ vs. $G$ and 3.26 in B vs. D; these latter two are the most widely separated subpopulations (Figure 1). However, Mantel test revealed no significant correlation between geographical and genetic distances at subpopulation level $(r=0.402 ; p=0.256)$.

UPGMA clustering based on Nei's genetic distances (Figure S2) revealed a close relationship between subpopulations $A$

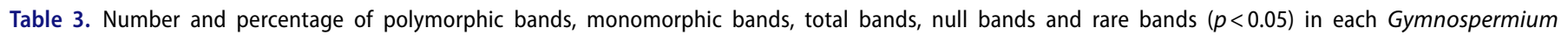
eddae subpopulation.

\begin{tabular}{lcccccccccc}
\hline Subpopulation & $\mathrm{n}$ & $\begin{array}{c}\text { Polymorphic } \\
\text { bands }\end{array}$ & $\begin{array}{c}\text { \% of polymorphic } \\
\text { bands }\end{array}$ & $\begin{array}{c}\text { Monomorphic } \\
\text { bands }\end{array}$ & Total bands & Null bands & $\begin{array}{c}\text { Rare bands } \\
(p<0.05)\end{array}$ & $\mathrm{N}_{\mathrm{e}}$ & $\mathrm{H}_{\mathrm{e}}$ & $\mathrm{I}$ \\
\hline $\mathbf{A}$ & 30 & 64 & 62.75 & 24 & 88 & 14 & 10 & 1.345 & 0.197 & 0.296 \\
B & 30 & 71 & 69.61 & 20 & 91 & 11 & 12 & 1.375 & 0.218 & 0.329 \\
C & 30 & 61 & 59.80 & 24 & 85 & 17 & 7 & 1.316 & 0.187 & 0.283 \\
D & 35 & 52 & 50.98 & 27 & 79 & 23 & 6 & 1.283 & 0.169 & 0.254 \\
G & 9 & 45 & 44.12 & 30 & 75 & 27 & 0 & 1.280 & 0.162 & 0.240 \\
Mean & - & $\mathbf{5 8 . 6}$ & $\mathbf{5 7 . 4 5}$ & $\mathbf{2 5}$ & - & $\mathbf{1 8 . 4}$ & $\mathbf{7}$ & $\mathbf{1 . 3 2 0}$ & $\mathbf{0 . 1 8 7}$ & $\mathbf{0 . 2 8 0}$ \\
Total & $\mathbf{1 3 4}$ & $\mathbf{8 5}$ & $\mathbf{8 3 . 3 3}$ & $\mathbf{1 7}$ & $\mathbf{1 0 2}$ & $\mathbf{9 2}$ & $\mathbf{2 6}$ & $\mathbf{1 . 3 5 9}$ & $\mathbf{0 . 2 1 0}$ & $\mathbf{0 . 3 2 0}$ \\
\hline
\end{tabular}

$\mathrm{N}_{\mathrm{e}}=$ effective number of fragments per locus; $\mathrm{H}_{\mathrm{e}}=$ Nei's genetic diversity; $\mathrm{I}=$ Shannon-Weaver diversity index. 


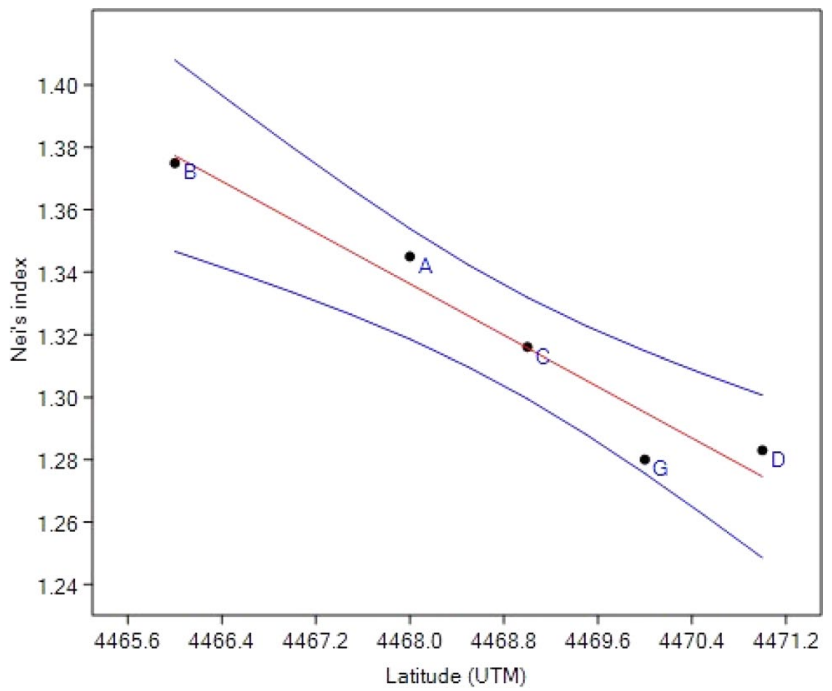

Figure 2. Relationship between Nei's genetic diversity index and latitude, expressed as kilometers from the equator (UTM projection), in the subpopulations of Gymnospermium eddae (A-G). Labels according to Figure 1 and Table 3.

and $B$, which resulted linked to subpopulation $C$. A second cluster joined together subpopulations $D$ and $G$. The first two axes extracted by the PCoA analysis of all the individuals explained only $9.5 \%$ and $9.3 \%$ of the total variation, respectively, with no clustering of plants from the same subpopulation (Figure 3).

The Bayesian method implemented in STRUCTURE provided further evidence about population structure in $G$. eddae. The Delta $\mathrm{K}$ test suggested that our sample was made up of three main genetic groups $(K=3)$, with the second largest peak at $\mathrm{K}=5$ (Supplementary Materials Figure S3). The proportion of each of these groups in all individuals examined is shown in Figure 4. At $\mathrm{K}=3$, three clusters were separated with no clear evidence of a relationship with the geographical position of subpopulations. The first cluster $\left(\mathrm{K} 1, \mathrm{~F}_{\mathrm{ST}}=0.217\right.$; blue colour in Figure 4) was composed of 27 individuals belonging mainly to subpopulations $B$ and $C$, while no individuals of subpopulation $G$ were included in genetic group $\mathrm{K} 1$; the second cluster $\left(\mathrm{K} 2, \mathrm{~F}_{\mathrm{ST}}=0.153\right.$; red colour in Figure 4) included 74 individuals, most of them of subpopulation $\mathrm{D}$; the third cluster $\left(\mathrm{K} 3, \mathrm{~F}_{\mathrm{ST}}=0.169\right.$; green colour in Figure 5) was composed of 33 individuals. Subpopulations $B$ and $D$ were, respectively, the most heterogeneous $\left(\mathrm{H}_{\mathrm{e}}=0.218\right)$ and the most homogeneous $\left(\mathrm{H}_{\mathrm{e}}\right.$ $=0.169$ ).

Finally, the mismatch analysis revealed a unimodal pattern except for subpopulation G, which showed a multimodal mismatch distribution (Figure 5).

\section{Discussion}

In the present study, dominant molecular markers provided the first insights into the population genetics of G. eddae, a highly endangered endemic of the southern Apennines that was only recently described (Rosati et al. 2019a). For the purposes of this study, we have ascertained the presence of only four relatively large subpopulations and two small subpopulations with very few individuals ( $G$ in Table and Figure 1). Unfortunately, no information is available about past occurrence and consistence of populations of this taxon.

Using RAPDs allowed comparing results with those concerning G. microrrhyncum from South Korea, which was investigated with the same primers (Lee et al. 2016). As found in G. microrrhyncum, the highest and lowest percentages of polymorphic bands (PPB) in G. eddae were detected with the primers OPN-13 and OPAF-17, respectively (Table 2). At the population level, PPB was similar in the two taxa, with values ranging from 44.1 to $69.6 \%$, and 32.1 to $66.7 \%$ in G. eddae and G. microrrhyncum, respectively. Similar results were found for population genetic diversity, where mean $H_{e}$ values resulted almost identical $(G$. eddae $=0.187$; G. microrrhyncum $=0.188$ ). At species level, however, genetic diversity in $G$. eddae resulted lower $\left(\mathrm{H}_{\mathrm{e}}=0.210\right)$ than in $\mathrm{G}$. microrrhyncum $\left(\mathrm{H}_{\mathrm{e}}=0.349\right)$, likely due to the much larger range of the latter species and the genetic differentiation among its populations on the mountains of the Korean peninsula (Lee et al. 2016). Gymnospermium microrrynchum is in fact the most isolated species of the genus, from both a geographical and phylogenetic point of view (Loconte and Estes 1989; Barina et al. 2017; Rosati et al. 2019a).

Unfortunately, no data are available about genetic diversity in other Gymnospermium species, preventing a wider comparison of our results with especially the closely related Balkan taxa G. scipetarum/maloi. With respect to widespread species, narrow-ranged endemics are often assumed to display high differentiation among populations and low genetic variation within populations (e.g. Schaal et al. 1998; Moyle 2006). However, overall evidence not always supports this general pattern (e.g. Cole 2003; Duminil et al. 2007), including some Mediterranean plants (Forrest et al. 2017). Concerning Italian narrow endemics, recent works have reported variable levels of genetic diversity at species level (De Vita et al. 2009; Bacchetta et al. 2013; Vandepitte et al. 2013) supporting a dependence on the evolutionary history of each taxon and its specific life history traits. Our findings show that genetic variability of $G$. eddae $\left(\mathrm{H}_{\mathrm{e}}=0.210\right)$ is comparable to that reported for other southern Italian endemics investigated using dominant nuclear markers, such as the Sicilian paleoendemic Petagnaea gussonei (Spreng.) Rauschert $\left(\mathrm{H}_{\mathrm{e}}=0.246\right.$;

Table 4. Hierarchical analysis of molecular variance (AMOVA) for 102 RAPD loci in five subpopulations of Gymnospermium eddae. $p=$ probability for $\boldsymbol{\varphi}$ based on 9,999 permutations across the full data set.

\begin{tabular}{|c|c|c|c|c|c|c|c|}
\hline $\begin{array}{l}\text { Source of } \\
\text { variation }\end{array}$ & $\mathrm{df}$ & Sum of squares & $\begin{array}{c}\text { Variance } \\
\text { components }\end{array}$ & $\begin{array}{l}\text { Estimate } \\
\text { variance }\end{array}$ & $\begin{array}{c}\text { Percentage of } \\
\text { variation }\end{array}$ & $\begin{array}{c}\text { Genetic } \\
\text { differentiation } \varphi\end{array}$ & $p$ \\
\hline $\begin{array}{l}\text { Among } \\
\text { subpopulations }\end{array}$ & 4 & 153.149 & 38.287 & 1.090 & $9.89 \%$ & & \\
\hline $\begin{array}{l}\text { Within } \\
\text { subpopulations }\end{array}$ & 129 & 1280.508 & 9.926 & 9.926 & $90.11 \%$ & 0.099 & 0.0001 \\
\hline Total & 133 & 1433.657 & & 11.016 & $100 \%$ & & \\
\hline
\end{tabular}




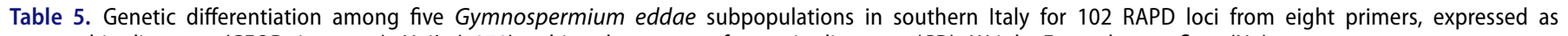
geographic distances (GEOD, in meter), Nei's (1978) unbiased measure of genetic distances (GD), Wright $\mathrm{F}_{\mathrm{ST}}$ and gene flow ( $\mathrm{N}_{\mathrm{m}}$ ).

\begin{tabular}{|c|c|c|c|c|}
\hline Subpopulation & GEOD (m) & GD & $\mathrm{F}_{\mathrm{ST}}$ & $\mathrm{N}_{\mathrm{m}}$ \\
\hline$A$ vs. $B$ & 1,556 & 0.0144 & 0.059 & 7.919 \\
\hline A vs. C & 1,705 & 0.0182 & 0.090 & 5.078 \\
\hline$A$ vs. D & 3,209 & 0.0260 & 0.104 & 4.298 \\
\hline A vs. $G$ & 2,253 & 0.0347 & 0.103 & 4.347 \\
\hline B vs. C & 3,252 & 0.0202 & 0.087 & 5.276 \\
\hline B vs. D & 4,750 & 0.0404 & 0.133 & 3.264 \\
\hline B vs. G & 3,774 & 0.0440 & 0.105 & 4.240 \\
\hline C vs. D & 1,517 & 0.0357 & 0.127 & 3.450 \\
\hline C vs. G & 1,054 & 0.0304 & 0.047 & 10.202 \\
\hline D vs. $G$ & 1,610 & 0.0316 & 0.089 & 5.126 \\
\hline
\end{tabular}

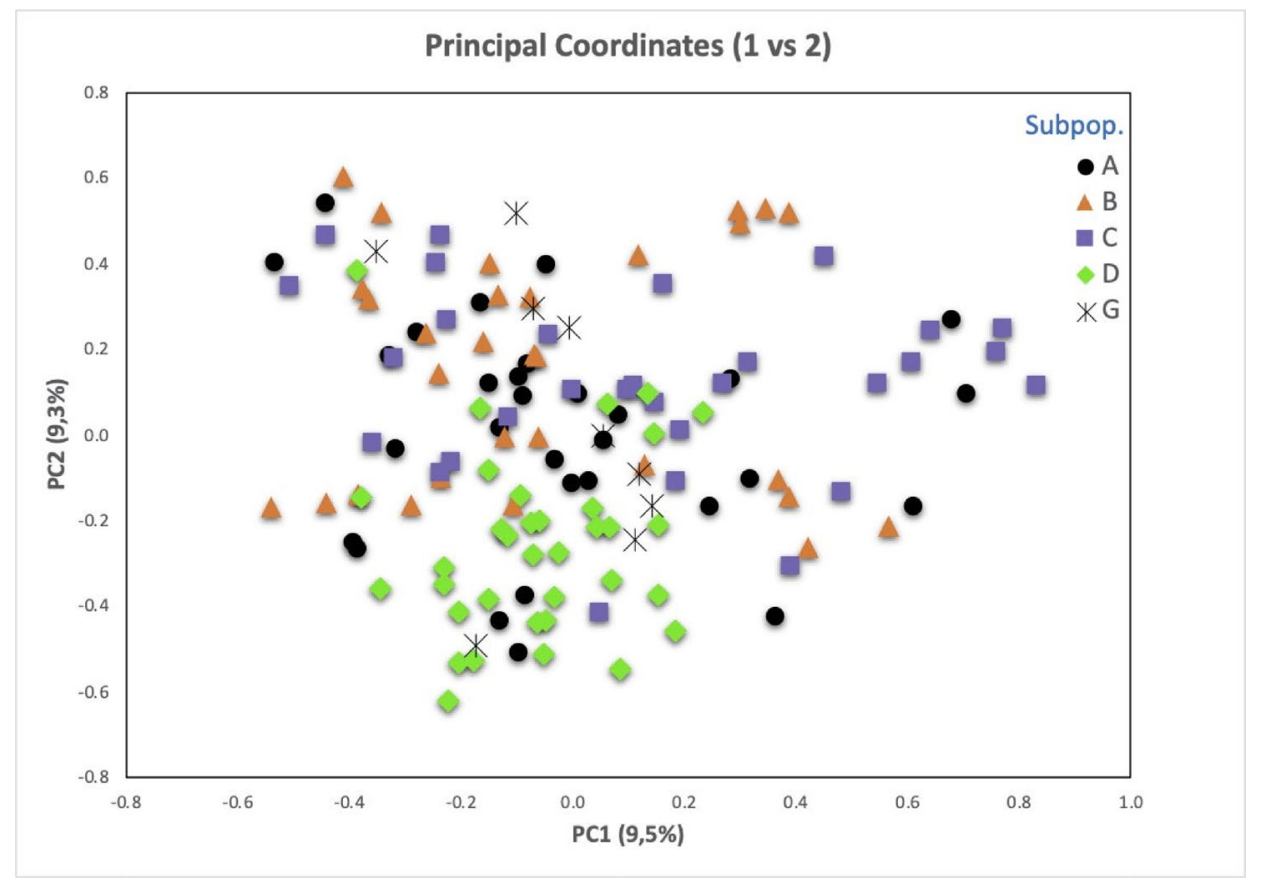

Figure 3. Principal coordinates analysis for all the Gymnospermium eddae individuals studied. Different colours and symbols are used for the five subpopulations analysed; blue $=\mathrm{A}$, orange $=\mathrm{B}$, green $=\mathrm{C}$; yellow $=\mathrm{D}$, brown $=\mathrm{G}$.

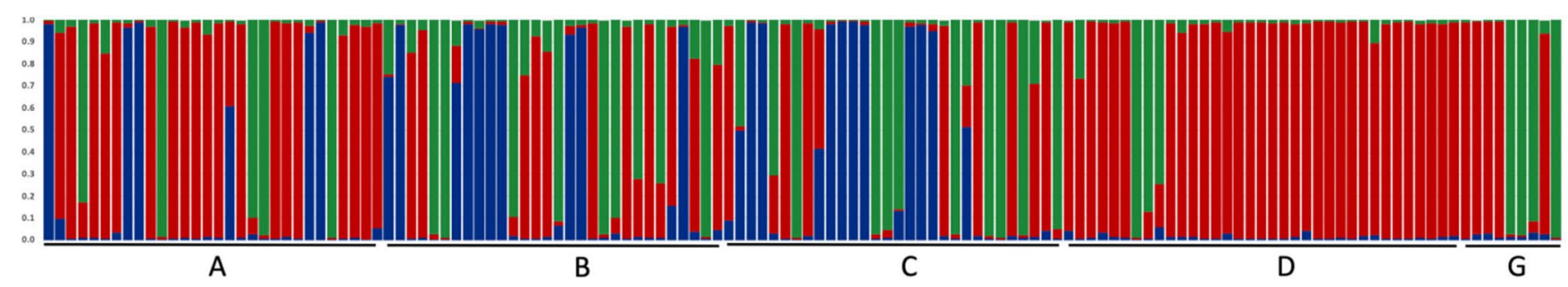

Figure 4. Population structure of Gymnospermium eddae individuals based on RAPD markers. Each individual is represented by a vertical line, and cluster assignments are indicated by colour; blue $=\mathrm{K} 1$, red $=\mathrm{K} 2$ and green $=\mathrm{K} 3 ; \mathrm{A}, \mathrm{B}, \mathrm{C}, \mathrm{D}$ and $\mathrm{G}$ are the five subpopulations analysed by $102 \mathrm{RAPD}$ bands.

De Castro et al. 2013) or the Calabrian neoendemic (patroendemic) Plantago media L. subsp. brutia (Ten.) Arcang. $\left(\mathrm{H}_{\mathrm{e}}\right.$ = 0.19; De Vita et al. 2009).

Regarding life history traits, the mean value of within-population genetic diversity in G. eddae (0.187) was lower than the reference values estimated with RAPDs markers reported by Nybom (2004) for endemic (0.20), long-lived perennials $(0.25)$, outcrossing (0.27) and late successional species (0.30). On the contrary, the value for G. eddae is in line with that reported by Nybom (2004) for plants dispersed by gravity (0.19). However, although the first comparative studies have strongly emphasized how species ecological attributes and life history traits can shape plant genetic structure (e.g. Nybom and Bartish 2000; Nybom 2004), only the mating system has been proved to be a significant factor in studies based on nuclear markers (Duminil et al. 2007).

Based on AMOVA results, differentiation among subpopulations of $G$. eddae was very weak, with as much as $90 \%$ of the variation occurring within subpopulations and a concomitant high level of estimated gene flow $\left(\mathrm{N}_{m}=5.320\right)$. Remarkably, this is in contrast with findings on G. microrrhyncum (Lee et al. 2016), which showed a higher 


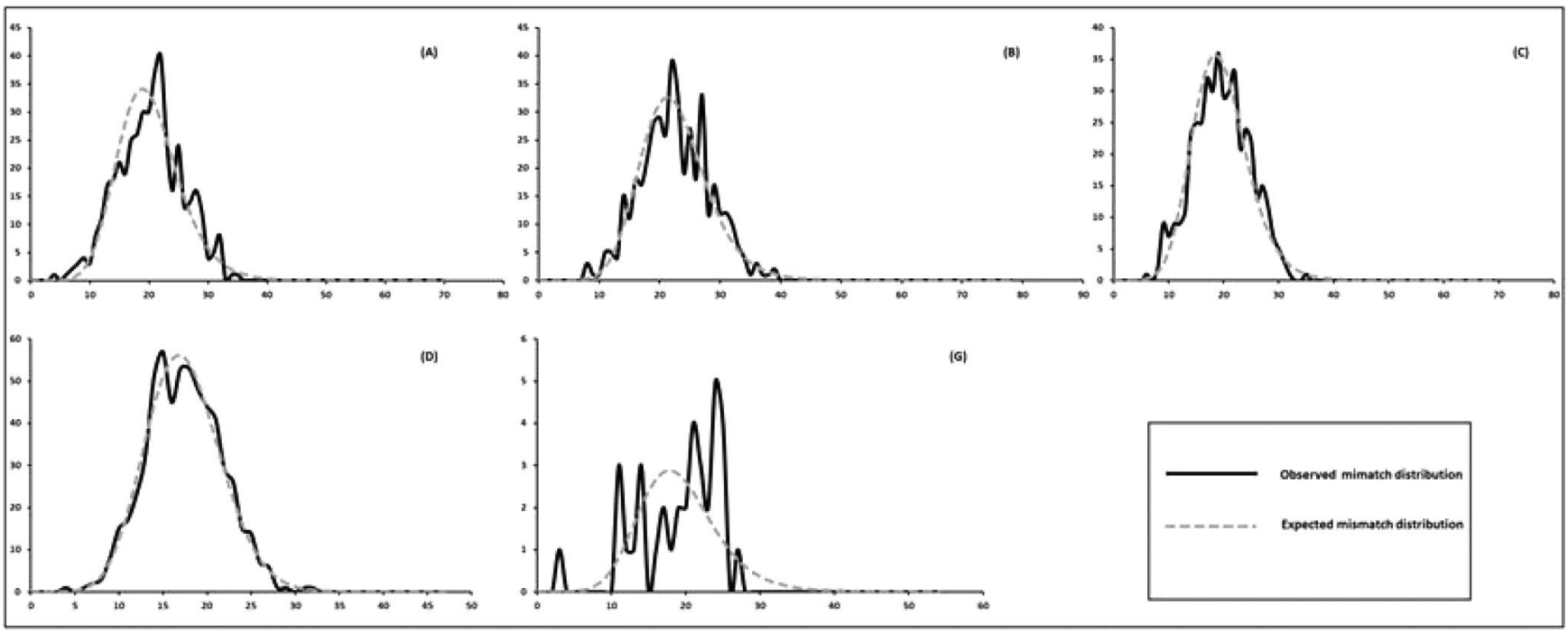

Figure 5. Mismatch distribution among samples in each subpopulation (codes as in Table 1). Abscissa shows the number of pairwise differences, ordinate the number of loci showing the mismatch.

differentiation among subpopulations (68\%) associated with a significantly lower level of gene flow value $\left(\mathrm{N}_{\mathrm{m}}=0.117\right)$. This opposite pattern is likely associated with the geographically wider and temporally longer separation between the populations of the Korean species, compared with closer proximity and possibly shorter isolation of the G. eddae subpopulations. Indeed, the high level of inter-population genetic divergence in G. microrrhyncum was interpreted as a consequence of Late Pleistocene inter-glacial phases that caused the isolation of these populations on distant mountain tops of the Korean peninsula (Chang et al. 2004; Lee et al. 2016). The large distance (up to $110 \mathrm{~km}$ ) between G. microrrhyncum populations was considered as the most important factor in maintaining differentiation between populations by preventing gene flow (Lee et al. 2016). On the contrary, STRUCTURE analysis and the Mantel test showed no geographic structuring of subpopulations in G. eddae, hence supporting a lack of isolation by distance (IBD). Since these subpopulations are scattered over a surface of only a few kilometres along the same mountain range and in similar forest habitats, the present-day distribution pattern could be the result of a relatively recent fragmentation process. However, genetic diversity was apparently related with latitude, as observed in G. microrrhyncum. In the latter, genetic diversity increased with latitude, suggesting it a relict plant of northern origin probably moved to more southern areas during the cold and dry climatic phase of the Late Pleistocene (Lee et al. 2016). In G. eddae, the opposite latitudinal trend of genetic variation, increasing from south to north, remains difficult to interpret also due to the much shorter geographical gradient involved. At the present state of knowledge, it could be either a random effect or a signal of past location of restricted refuge sites followed by a slow process of northward recolonization starting from one or more southern subpopulations. Support to the latter hypothesis may come from the northernmost subpopulation (D): although this is the largest in terms of occupancy area and number of individuals it is the most genetically depleted $\left(H_{e}=0.169\right)$, as a possible result of recent colonization processes following a consistent founder effect or genetic bottleneck (see also the results of STRUCTURE analysis below). A rapid growth of this population could have been enhanced by a past event of forest clearing, which has affected a narrow strip that crosses subpopulation D.

Based on the reproductive biology of the species (Rosati et al. 2019b), the levels of inter-population gene flow estimated for G. eddae were higher than expected. In fact, the heavy seeds of $G$. eddae, though equipped with a strofiole (lacking in G. microrrhyncum) interpreted as a specialization for myrmecochory (Lengyel et al. 2009), were experimentally demonstrated not to be dispersed by ants or any other animal vectors, but only by gravity (LR pers. obs.). Thus, dispersal mechanisms are not likely to contribute to gene flow among subpopulations. Also, the short-distance activity of the pollinating insects and their low frequency of visits (Rosati et al. 2019b) make a significant gene flow between subpopulations unlikely. The subpopulations are in fact several kilometres apart from each other and are separated by forest habitats with a scarce presence of foraging resources during the very early flowering period of $G$. eddae. Moreover, gene flow through pollen dispersal may be scarcely relevant for $G$. eddae, because the most common pollinators tend to forage on flowers of the same or neighbouring plants and pollinators are scarcely available during the flowering time because of the early season. Indeed, the rate of seed set of $G$. eddae is likely limited by pollen transfer, being $G$. eddae an obligated allogamous plant (Rosati et al. 2019b). Based on these observations, the gene flow could have been here overestimated by the $\mathrm{N}_{\mathrm{m}}$ index, and the poor genetic differentiation between the populations is due to recent fragmentation process rather than to a consistent gene flow by pollen transfer mediated by insects. On the other hand, it cannot be entirely excluded that pollinators may occasionally transport pollen over a long distance. A few studies supported that Diptera, the prevalent pollinators of $G$. eddae, can act as long-distance pollinators (e.g. Taroda and Gibbs 1982; Bänziger 1991) and also some of the rarest pollinators of this 
species (e.g. bumblebees and bee-flies) are known to act as long-distance pollen vectors. In addition, our observations over several years showed low seedling survival and a relatively long time to reach the first flowering (sexual maturity), probably not less than 5 years, coupled with a very long life cycle, possibly spanning over several decades. In conclusion, it still remains difficult to establish whether the observed low inter-population divergence among the subpopulations of $G$. eddae is constitutive, shaped by a relatively recent fragmentation process, or maintained by gene flow (albeit occasional) via long-distance pollen transfer.

Concerning vegetative reproduction, genetic distances among individuals did not support occurrence of this type of reproduction in $G$. eddae, thus confirming our preliminary observations that this plant reproduces only sexually.

Since this study concerns a rare and endangered species, it was especially important to estimate the most probable number of "genetic units" or "gene pools" (K value), to propose conservation recommendations also in the light of the possible mechanisms that have shaped the species genetic variability. A sharp signal was found at $K=3$, therefore suggesting that three genetic groups constitute the bulk of the genetic pool of $G$. eddae. At present, however, these three gene groups are mostly found in more than a single subpopulation, thus pointing to a general situation of genetic admixing in most subpopulations. This result is in line with the low inter-population differentiation and the similar levels of genetic variation within subpopulations. A notable exception was represented by subpopulation $D$, that showed a higher genetic homogeneity due to the strong dominance of genetic group 2 and the very minor incidence of groups 1 and 3. As discussed above, founder effects followed by demographic expansion could explain this result and the lower genetic diversity of this subpopulation.

Moreover, the lower genetic diversity in subpopulation G, coupled with the multimodal distribution of differences between all pairs of individuals and the dominance of two out of three genetic groups identified by the STRUCTURE analysis, may suggest multiple independent introgression of individuals during the recent history of the population.

\section{Conservation implications}

Our data on genetic structure of $G$. eddae can assist both in-situ and ex-situ conservation actions. These should aim at preserving the highest possible amount of genetic diversity of the taxon and should be urgently carried out in order to ensure its survival in the long-term.

The strategy of in-situ conservation necessarily implies the strict protection of all areas and habitat conditions where natural populations exist in order to preserve the extant genetic diversity. In addition, a dedicated monitoring program aimed at detecting early signs of population decline and the presence of specific threats to the survival of this species should be urgently started.

For the purpose of precautionary conservation, and to have plant material for possible reinforcement and reintroduction actions, it is also necessary to establish one or more ex-situ collections of this species in botanical gardens. To achieve this objective, due to the low and evenly distributed genetic variability, it could be sufficient to collect seeds from a few dozens of individuals per population to capture the majority of the genetic variation held within the species. Since we found no evidence of a clear genetic differentiation between the remnant populations, all extant subpopulations can be considered as a single conservation unit. However, it should be avoided to sample seeds only from subpopulation $D$, the largest one, as this would entail a high risk of having only a low level of gene diversity represented in ex-situ subpopulations. On the contrary, the southern subpopulations $B$ and $A$ takes a clear priority for their higher level of genetic diversity and for the presence of several private bands.

Also, it is important to observe that ex-situ cultivation represents the only practical way to conserve the germplasm of $G$. eddae, as it does not seem possible to preserve viable seeds after dehydration (LR pers. observ.)

Moreover, the low number of subpopulations and the small area of occupancy suggest reintroduction actions to establish new populations in suitable habitats in order to enhance connectivity of remnant populations. For both extant populations and newly established ones, an adequate density of plants is necessary to achieve a successful reproduction, since $G$. eddae is a self-incompatible species.

Finally, since the whole extant range of $G$. eddae is included within a Natura 2000 site, it is crucial that monitoring and conservation actions for the in-situ conservation of this endemism are explicitly included in the management plan of the site IT8050034 "Monti della Maddalena."

\section{Acknowledgements}

LR thanks funding from Fondo di finanziamento per le attività base di ricerca (FFABR 2017), University of Basilicata; EF thanks funding from Fondo di Ateneo per la ricerca 2019 (FAR-2019), University of Sassari.

\section{Disclosure statement}

No potential conflict of interest was reported by the authors.

\section{Funding}

Università degli Studi della Basilicata;Università degli Studi di Sassari.

\section{ORCID}
S. Fascetti (ID http://orcid.org/0000-0001-6870-0108
A. Coppi (D) http://orcid.org/0000-0003-4760-8403
F. Selvi (iD http://orcid.org/0000-0002-3820-125X
E. Farris (ID http://orcid.org/0000-0002-9843-5998
L. Rosati (ID http://orcid.org/0000-0003-4247-6157

\section{References}

Bacchetta G, Fenu G, Gentili R, Mattana E, Sgorbati S. 2013. Preliminary assessment of the genetic diversity in Lamyropsis microcephala (Asteraceae). Plant Biosyst Int J Deal Asp Plant Biol. 147(2):500-507.

Bänziger H. 1991. Stench and fragrance: unique pollination lure of Thailand's largest flower, Rafflesia kerrii Meijer. Nat Hist Bull Siam Soc. 39:19-52. 
Barina Z, Caković D, Pifkó D, Schönswetter P, Somogyi G, Frajman B. 2017. Phylogenetic relationships, biogeography and taxonomic revision of European taxa of Gymnospermium (Berberidaceae). Bot J Linn Soc. 184(3):298-311.

Chang C-S, Kim H, Park T-Y, Maunder M. 2004. Low levels of genetic variation among southern peripheral populations of the threatened herb, Leontice microrhyncha (Berberidaceae) in Korea. Biol Conserv. 119(3):387-396.

Cole CT. 2003. Genetic variation in rare and common plants. Annu Rev Ecol Evol Syst. 34(1):213-237.

Conte L, Cotti C, Schicchi R, Raimondo FM, Cristofolini G. 2004. Detection of ephemeral genetic sub-structure in the narrow endemic Abies nebrodensis (Lojac.) Mattei (Pinaceae) using RAPD markers. Plant Biosyst Int J Deal Asp Plant Biol. 138(3):279-289.

Coppi A, Mengoni A, Selvi F. 2008. AFLP fingerprinting of Anchusa (Boraginaceae) in the Corso-Sardinian system: genetic diversity, population differentiation and conservation priorities in an insular endemic group threatened with extinction. Biol Conserv. 141(8):20002011.

De Castro O, Sepe F, Di Maio A, Cennamo P, De Luca P, Gianguzzi L, Menale B. 2013. Genetic structure in the paleoendemic and endangered Petagnaea gussonei (Spreng.) Rauschert (Saniculoideae, Apiaceae) and implications for its conservation. Plant Syst Evol. 299(1):209-223.

De Vita A, Bernardo L, Gargano D, Palermo AM, Peruzzi L, Musacchio A 2009. Investigating genetic diversity and habitat dynamics in Plantago brutia (Plantaginaceae), implications for the management of narrow endemics in Mediterranean mountain pastures. Plant Biol (Stuttg). 11(6):821-828.

Di Cecco V, Di Santo M, Di Musciano M, Manzi A, Di Cecco M, Ciaschetti G, Marcantonio G, Di Martino L. 2020. The Majella National Park: a case study for the conservation of plant biodiversity in the Italian Apennines. Italian Botan. 10:1-24.

Duminil J, Fineschi S, Hampe A, Jordano P, Salvini D, Vendramin GG, Petit RJ. 2007. Can population genetic structure be predicted from life-history traits? Am Nat. 169(5):662-672.

Earl DA, von Holdt BM. 2012. STRUCTURE HARVESTER: a website and program for visualizing STRUCTURE output and implementing the Evanno method. Conservation Genet Resour. 4(2):359-361.

Ellstrand NC, Elam DR. 1993. Population genetic consequences of small population size: implications for plant conservation. Annu Rev Ecol Syst. 24(1):217-242.

Excoffier L, Lischer HEL. 2010. Arlequin suite ver 3.5: a new series of programs to perform population genetics analyses under Linux and Windows. Mol Ecol Resour. 10(3):564-567.

Excoffier L, Smouse PE, Quattro JM. 1992. Analysis of molecular variance inferred from metric distances among DNA haplotypes: application to human mitochondrial DNA restriction data. Genetics. 131(2):479491.

Forrest A, Escudero M, Heuertz M, Wilson Y, Cano E, Vargas P. 2017. Testing the hypothesis of low genetic diversity and population structure in narrow endemic species: the endangered Antirrhinum charidemi (Plantaginaceae). Bot J Linn Soc. 183(2):260-270.

Frankham R. 2005. Genetics and extinction. Biol Conserv. 126(2):131-140. Gioia T, Logozzo G, Attene G, Bellucci E, Benedettelli S, Negri V, Papa R, Spagnoletti Zeuli P. 2013. Evidence for introduction bottleneck and extensive inter-gene pool (Mesoamerica $x$ Andes) hybridization in the European common bean (Phaseolus vulgaris L.) germplasm. PLOS One. 8(10):e75974.

González-Astorga J, Castillo-Campos G. 2004. Genetic variability of the narrow endemic tree Antirhea aromatica Castillo-Campos Lorence, (Rubiaceae, Guettardeae) in a tropical forest of Mexico. Ann Bot. 93(5):521-528.

Hammer $\varnothing$, Harper DAT, Ryan PD. 2001. PAST: Paleontological statistics software package for education and data analysis. Palaeontol Electronic. 4(1):9. http://palaeo-electronica.org/2001_1/past/issue1_01.htm.
Hartl DL, Clark AG. 1989. Principles of population genetics. 2nd ed. Sinauer Associates. Sunderland, MA.

Hatmaker EA, Staton ME, Dattilo AJ, Hadziabdic $Đ$, Rinehart TA, Schilling EE, Trigiano RN, Wadl PA. 2018. Population structure and genetic diversity within the endangered species Pityopsis ruthii (Asteraceae). Frontiers in Plant Science [Internet]. [accessed 2021 Mar 19] 9. https:// www.frontiersin.org/article/10.3389/fpls.2018.00943/full.

Heywood VH. 2019. Conserving plants within and beyond protected areas - still problematic and future uncertain. Plant Divers. 41(2):3649

Jacquemyn H, De Meester L, Jongejans E, Honnay O. 2012. Evolutionary changes in plant reproductive traits following habitat fragmentation and their consequences for population fitness: Habitat fragmentation and plant trait evolution. J Ecol. 100(1):76-87.

Jiménez-Mejías P, Fernández-Mazuecos M, Amat ME, Vargas P. 2015. Narrow endemics in European mountains: high genetic diversity within the monospecific genus Pseudomisopates (Plantaginaceae) despite isolation since the late Pleistocene. J Biogeogr. 42(8):1455-1468.

Jump AS, Marchant R, Peñuelas J. 2009. Environmental change and the option value of genetic diversity. Trends Plant Sci. 14(1):51-58.

Ku Y-B, Oh H-K, Kong H-Y, Suh MH, Lee M-H, Trybush S, Cho K-H. 2004. Genetic diversity and differentiation in remnant populations of Bupleurum latissimum Nakai, an endangered endemic plant species to Ulleung Island, Korea. Korean J Biol Sci. 8(4):289-294.

Landuyt D, Lombaerde ED, Perring MP, Hertzog LR, Ampoorter E, Maes SL, Frenne PD, Ma S, Proesmans W, Blondeel H, et al. 2019. The functional role of temperate forest understorey vegetation in a changing world. Glob Chang Biol. 25(11):3625-3641.

Lee SH, Yeon MH, Shim JK. 2016. Conservation implications of the genetic diversity of Gymnospermium microrrhynchum in Korea. Genet Mol Res. 15:gmr15048843.

Leimu R, Mutikainen P, Koricheva J, Fischer M. 2006. How general are positive relationships between plant population size, fitness and genetic variation? J Ecol. 94(5):942-952.

Lengyel S, Gove AD, Latimer AM, Majer JD, Dunn RR. 2009. Ants sow the seeds of global diversification in flowering plants. PLoS ONE. 4(5):e5480.

Loconte H, Estes JR. 1989. Generic relationships within Leonticeae (Berberidaceae). Can J Bot. 67(8):2310-2316.

Marshall DR, Brown HD. 1975. Optimum sampling strategy in genetic conservation. In: Frankel $\mathrm{OH}$, and Hawkes JG, editors, Crop genetic resources for today and tomorrow, Cambridge University Press, London, p. 53-80.

Marzario S, Logozzo G, David J, Zeuli P, Gioia T. 2018. Molecular genotyping (SSR) and agronomic phenotyping for utilization of durum wheat (Triticum durum Desf.) ex situ collection from southern Italy: a combined approach including pedigreed varieties. Genes. 9(10):465.

Medail F, Quezel P. 1999. Biodiversity hotspots in the mediterranean basin: setting global conservation priorities. Conserv Biol. 13(6):15101513.

Moyle LC. 2006. Correlates of genetic differentiation and isolation by distance in 17 congeneric Silene species: genetic differentiation within Silene species. Mol Ecol. 15(4):1067-1081.

Myers N, Mittermeier RA, Mittermeier CG, da Fonseca GA, Kent J. 2000. Biodiversity hotspots for conservation priorities. Nature. 403(6772):853858.

Nei M. 1978. Estimation of average heterozygosity and genetic distance from a small number of individuals. Genetics. 89(3):583-590.

Nei M. 1987. Molecular evolutionary genetics. Columbia University Press. Nybom H. 2004. Comparison of different nuclear DNA markers for estimating intraspecific genetic diversity in plants: DNA-markers and plant genetic diversity. Mol Ecol. 13(5):1143-1155.

Nybom H, Bartish IV. 2000. Effects of life history traits and sampling strategies on genetic diversity estimates obtained with RAPD markers in plants. Perspect Plant Ecol Evol Syst. 3(2):93-114. 
Peakall R, Smouse PE. 2012. GenAIEx 6.5: genetic analysis in Excel. Population genetic software for teaching and research-an update. Bioinformatics. 28(19):2537-2539.

Pritchard J, Stephens M, Donnelly P. 2000. Inference of population structure using multilocus genotype data. Genetics. 155(2):945-959.

Ramos JR, Telles MPC, Diniz-Filho JAF, Soares TN, Melo DB, Oliveira G. 2008. Optimizing reproducibility evaluation for random amplified polymorphic DNA markers. Genet Mol Res. 7(4):1384-1391.

Rogers AR, Harpending H. 1992. Population growth makes waves in the distribution of pairwise genetic differences. Mol Biol Evol. 9(3):552-569.

Rosati L, Farris E, Tilia G, Potenza G, Fascetti S. 2014. Gymnospermium scipetarum (Berberidaceae) specie nuova per la flora italiana. In: Floristica Sistematica ed Evoluzione. Società Botanica Italiana. p. 7-8. DOI: 10.1093/aobpla/plw002.

Rosati L, Coppi A, Farris E, Fascetti S, Becca G, Peregrym M, Tan K, Selvi F. 2019a. The genus Gymnospermium (Berberidaceae) in Italy: identity and relationships of the populations at the western limit of the genus range. Plant Biosyst. 153(6):796-808.

Rosati L, Romano VA, Cerone L, Fascetti S, Potenza G, Bazzato E, Cillo D, Mecca M, Racioppi R, D'Auria M, et al. 2019b. Pollination features and floral volatiles of Gymnospermium scipetarum (Berberidaceae). J Plant Res. 132(1):49-56.

Schaal BA, Hayworth DA, Olsen KM, Rauscher JT, Smith WA. 1998. Phylogeographic studies in plants: problems and prospects. Mol Ecol. 7(4):465-474.

Schlaepfer DR, Braschler B, Rusterholz H-P, Baur B. 2018. Genetic effects of anthropogenic habitat fragmentation on remnant animal and plant populations: a meta-analysis. Ecosphere. 9(10):e02488.
Slatkin M, Barton NH. 1989. A comparison of three indirect methods for estimating average levels of gene flow. Evolution. 43(7):1349-1368.

Slatkin M, Hudson RR. 1991. Pairwise comparisons of mitochondrial DNA sequences in stable and exponentially growing populations. Genetics. 129(2):555-562.

Solórzano S, Arias S, Dávila P. 2016. Genetics and conservation of plant species of extremely narrow geographic range. Diversity. 8(4):31.

Taroda N, Gibbs PE. 1982. Floral biology and breeding system of Sterculia chicha St. Hil. (Sterculiaceae). New Phytol. 90(4):735-743.

Thompson JD. 2020. Plant evolution in the Mediterranean: insights for conservation, 2nd ed. Oxford University Press, New York.

Torres E, Iriondo JM, Perez C. 2003. Genetic structure of an endangered plant, Antirrhinum microphyllum (Scrophulariaceae): allozyme and RAPD analysis. Am J Bot. 90(1):85-92.

Turchetto C, Segatto ALA, Mäder G, Rodrigues DM, Bonatto SL, Freitas LB. 2016. High levels of genetic diversity and population structure in an endemic and rare species: implications for conservation. AoB Plants. 8:plw002.

Vandepitte K, Gristina AS, De Raedt R, Roldán-Ruiz I, Marcenò C, Sciandrello S, Honnay O. 2013. Conservation genetics of an endemic from the Mediterranean Basin: high genetic differentiation but no genetic diversity loss from the last populations of the Sicilian Grape Hyacinth Leopoldia gussonei. Conserv Genet. 14(5):963-972.

Wright S. 1978. Variability within and among natural populations. Vol. 4. The University of Chicago Press. Chicago, IL.

Yeh FC, Boyle TJB. 1997. Population genetic analysis of co-dominant and dominant markers and quantitative traits. Belgian J Bot. 129:157-163. 